\title{
Cinemas in the City: Berlin's Public Space in the 1910s and 1920s
}

\author{
- Brigitte Flickinger
}

The nightmare had melted into the keen, sweet sensation of absolute freedom, peculiar to sinful dreams.

V. Nabokov, Laughter in the Dark

Before the novelist Vladimir Nabokov, an émigré from Russia, became the famous 'American' writer, he lived in Berlin for more than a decade from 1922. Through crucial familial incidents and the beginning of his literary career, his life was intimately connected with the German capital and its urban culture. ${ }^{1}$ In his Berlin years Nabokov wrote (still in Russian) the novel Kamera obskura, which a few years later he revisited for an American edition, called Laughter in the Dark. ${ }^{2}$ Its plot is simple. As Nabokov himself put it: 'There lived in Berlin, Germany, a man called Albinus. He was rich respectable happy; one day he abandoned his wife for the sake of a youthful mistress; he loved; was not loved, and his life ended in disaster.

Set in the late period of the silent film and located in post-war Berlin, in about 1928, this novel unfolds into an homage to the 'velvety darkness' (20) of Berlin film-theatres of that time. Even more, it seems to encapsulate exemplarily the correlation of cinema and the city, of film life on the screen and real urban life under the conditions of fears and aspirations of pre- and post-First World War modernity in Berlin. So before we look at other evidence about this city and its complex relation to cinema, we can use Nabokov's novel for a vivid first impression.

Albert Albinus, Nabokov's affluent middle-class hero, has emerged from the war unscathed and enjoys a carefree life in post-war Berlin, thanks to his father's inheritance and his own business in the art trade, being an art expert and collector with contacts as far afield as America. Privately he is tied to a traditional bourgeois family life, with his inconspicuous wife and daughter. Living in a plush spacious flat in a respectable residential area at Kaiserallee, Berlin-

Wilmersdorf, ${ }^{3}$ he occasionally brightens his all-too conventional life by giving parties with a touch of extravagance. In the crisis-ridden post-war years of inflation and unemployment, of dubious profiteering alongside poverty, his guests, artists and would-be artists from the fine arts and film, are themselves short of money and are therefore happy to spend an indulgent evening in the rather dull company that Albinus represents (42). But despite his bourgeois life style, Albinus is attracted by the possibilities of the new media. He is seeking a producer to realize his film idea of animating famous paintings.

The seductiveness of cinema becomes ubiquitous in this novel. Film and cinema shape its form, style and contents. When Albinus (literally 'the White') retreats into the Black - the darkness of a rather unattractive suburban cinema named 'Argus' 4 - to while away a few hours of uncertainty in an area of the city unknown to him, he does so as an occasional customer for mere distraction. But then the cinema - and it is cinema, rather than film ${ }^{5}-$ utterly absorbs him. It evokes adventurous fantasies that stimulate his imagination, capture his mind and take him out of his everyday life. From this point cinema becomes for Albinus a substitute, a means of freeing himself of the constraints of his conventional bourgeois family life. In fact, by dreaming in the cinema of a 
film-like amorous affair he brings himself in his real life into a film-like catastrophe. The promising darkness of the Berlin cinemaauditorium leaves him in the end in an all-too-real, true darkness. His eventual blindness is the result of a car-crash he causes while on a euphoric journey with his eighteen-year-old sweetheart, Margot the usherette.

She, meanwhile, dreams of a glittering career as a film star in Berlin's burgeoning glamorous film world or, even better, in Hollywood. This, Margot believes, would miraculously free her from the meagre working class existence that her family ekes out in one of Berlin's notorious overcrowded Mietskasernen (city tenement blocks), where beatings, alcohol and prostitution are a normal part of growing up. When she gets a job as an usherette in a suburban Berlin cinema and Albinus enters, two individuals' desires to sweep aside social constraints coincide.

Margot drops her far-fetched hopes and makes her film plot come true on the spot. She concentrates purposefully on taking advantage of the naivety and wealth of her new-found admirer and his seemingly influential connections, including Axel Rex, a would-be film producer, whom she takes as a secret lover. Albinus, unable to see her motives, enjoys his escapade in what he regards as the modern Bohemian world. When the confusion of film fantasy and real life culminates in his bodily and social breakdown and loss of sight - making him totally dependent on his 'usherette' - he finally 'sees' what has been done to him. Though still caught up in his cinematic aberration, Albinus has only one aim: to take heroic revenge on Axel and Margot. Albinus, the betrayed, rushes by taxi through Berlin's streets from Tiergarten to Wilmersdorf to fight (in the best Hollywood manner) for higher justice, but pays dramatically with his own life. Only a narrator like Nabokov could keep such a shady, almost kitschy film story, embedded in 1920s' Berlin city life, in a morally neutral vagueness and on such an artistically high level.

What do we learn about the cinema-going experience in Berlin of the 1920s from this piece of fiction by a contemporary witness? And what are the questions that follow from it? First of all, Nabokov, who had to earn a living in Berlin from his writing could obviously expect that the cinema topic was popular enough to attract readers. The contemporary Berlin setting required authenticity in concrete details, in the plausibility of the fictional characters and in the composition as a whole. Indeed the novel gives precise topographical information; it alludes to the technological achievements that accompanied comfortable modern living in the better areas of the capital, such as electricity, bathrooms, telephones, central heating, lifts, gramophones and taxis. It also portrays leisure activities such as sports (ice hockey), arts, theatre, cafés; and the 'lower' ones of dancing, bars, and going on sprees. It shows some of the differences between the life of middle class people, the working class and the efforts some made to gain social advancement.

Years later Nabokov gave a frank assessment of his Berlin work. He called his figures 'hopeless clichés', while admitting that they were meant to be stereotypical. ${ }^{6}$ The 'real lives' of his two main characters in Laughter in the Dark are indeed reduced to something like Hollywood film roles, while the film on the screen, which they both attend at the 'Argus' without watching it, is not even worth mentioning in the novel. The implication is that it is dull, or, as the critics of German and American films alike would have agreed in the mid-1920s, that it is an unimaginative work of series production without any cultural value.

But if the particular films screened are not important for Nabokov, the cinema itself, the space of cinema, does play a crucial role in this Berlin novel, and that is my primary interest here. I shall follow Nabokov's switch of viewpoint from the film to the cinema, considering cinema as an important medium in itself. This seems to make particular sense for the German post-war period. ${ }^{7}$ I shall argue therefore that the cinema went on playing a decisive role in urban culture, even during the many economic and financial crises before and after the war, and despite the crisis of the German film industry in the mid1920 s when the trade temporarily registered 
drops in attendance figures. ${ }^{8}$ As has been recently argued, in Europe from the turn of the century 'cinema, cinema culture and urban culture became intertwined [ . . . ] Cinema became an "institution" of urban social life". 9 Viewing cinema as a factor in the public sphere shifts our attention from the main interests of film history and of the history of the film industry, focusing instead on cinema-goers and how their cinema-going fits in to the broader context of their lives in the city.

For a long time research in film history was chiefly based on the dates and figures of the film industry, and this with good reason. The film industry, almost from the beginning, was a selfreflective business. It watched its profitability and published its results, its expectations, hopes and fears, regarding its business interests with modern rationality. That made its records undoubtedly an invaluable source for film historians. But are the trade figures really also a significant indicator for peoples' tastes and likings? Do the statistics of cinemas really show the social relevance, worth and value of the new medium? Did the public, for instance in Berlin, when attendance figures dropped in 1925, really lose its interest and desire for cinema-going?

An observation in Wolffsohn's Yearbook of the Film industry itself is socially and theoretically revealing.

The increase [in the opening of film theatres] was hindered by the economic situation of the country. [ . . ] ] It is this economic plight that gives our cinema-going a different form than for instance in America. Most of our cinema-goers go once a week and this usually on the day of payment of wages or shortly afterwards. Therefore [for the cinema owner] there are on average usually three good and four bad days in the week. So that on good days there are not enough seats while on bad days most of them stay empty. ${ }^{10}$

Cinema was a result of modern progress in technology, chemistry and electrical engineering. But it was also productive in contributing to the social and mental changes in urban life. As we saw in Laughter in the Dark, cinema was capable of bringing together people from different strata of society who otherwise hardly would have met or been in social contact with one another. ${ }^{11}$ In the transitional period of the Weimar Republic, when traditional thoughts and values clashed with the experiences of the modern industrial world of 'the masses', of mass consumption and conformity, cinema was able to function as a bridge between disparate forms of social behaviour. ${ }^{12}$ Thus cinema was an opportunity and a temptation. The darkness in front of a film screen made intimacy sociable and drove on the imagination to new roles and unfamiliar identities.

In fact Laughter in the Dark is grounded in the socio-economic as well as the mental and intellectual state of the era, especially of Berlin. It connects this basis with the mental escape which the 'cult of distraction' offers in the cinema. ${ }^{13}$ For many citizens, cinema was an attraction that lured them out of an often hard and uncertain existence governed by threats of unemployment, overproduction, rationalization of work processes, alienation and loneliness within mass urban society. They fled into the light and optimistic world of the dream palaces. Other citizens criticized the triviality of cinema entertainment and mass consumption in general. From their point of view, these undesirable American cultural imports had arrived along with Fordism and Taylorism, pragmatism and positivism, and would ruin European identity and culture. Although most of this critique had already emerged before the First World War, its reproaches culminated in the 1920 s and were discussed under the generalized topos of 'Americanism'. ${ }^{14}$

It seems telling that only few among those masses who then went to the movies talked or wrote about their experience. Those who did so, mostly felt committed to speak in general and with certain socio-political leanings and intentions. They engaged in topics like 'trashy literature and trashy cinema' or 'the fundamental differences' between 'high culture' and 'mere civilization'. They discussed what dangers the cinema might cause to physical and mental health. ${ }^{15}$ Other writers, on the contrary, emphasized the importance of 'the masses', of mass culture and the revolutionary power of 
modernity in film. While critical journalists from the Right turned up their noses at badly ventilated, dirty and uncomfortable fleapits, those from the Left welcomed the democratization of cultural consumption and appreciated that now also 'the little shop-girls go to the movies'. ${ }^{16}$ These discourses seem to be, as we shall see, themselves part of the story which later became film history.

During this period representative surveys of consumers in general and of film audiences in particular were not yet commercially undertaken. If they had been, they would have given us some insight into the motivations of the cinema-goers. To shed light on the role of cinema as a social medium we need to attend to the complexity of the urban context of which cinema was an integral part. ${ }^{17}$ Therefore we will turn first to Berlin's urban history, to find out what it was like in the 1910s and 1920s and what made it more easily prepared for the new media than any other city in Germany. Secondly, we will look at some particular cinemas to ask: What role did the quickly established 'Kintops' and the increasingly sophisticated 'Lichtspieltheater' (the 'light theatres') play for Berlin citizens? Furthermore, as steps three and four, we will consider how the weaknesses of the German film business and ongoing debates affected cinema-going in the city.

Cinema audiences, especially in these early years, can be considered as being in interplay with the conditions that made their leisure activities possible. These were shaped by the city they lived in, the cinemas they went to, the trade that provided cinema entertainment and the ongoing cultural debates within the public sphere - especially on cinema and its

'Americanization'. It is to these aspects of city life for the cinema-goer that I now turn.

\section{The city}

In the early 1900s Berlin was (as it still is) the largest German city, and from 1871 onwards it had the highest and most rapid increase of population. ${ }^{18}$ How fundamentally urban life changed within just three-and-a-half decades,

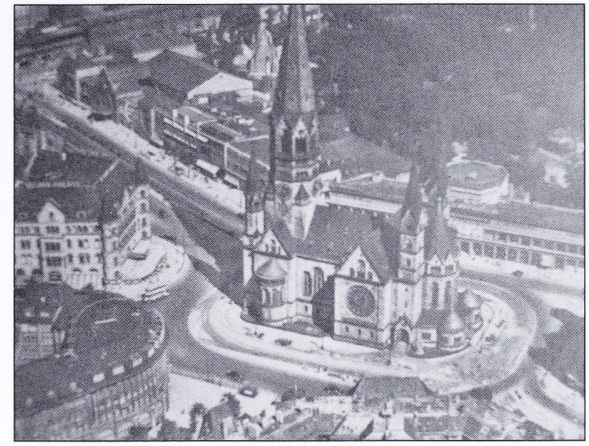

- The Kaiser Wilhelm Gedächtniskirche in the 1920 s marked the new centre of Berlin at the entrance to Kurfürstendamm. On the left: 'Gloria-Palast' in Romanisches Haus.

between the end of the nineteenth century and 1930, has been analyzed from many points of view. But its relation to the development of cinema has been as yet largely ignored. The changes that came with modernity were as radical in technology and economic organization as they were in social and cultural life. People living in Berlin in the 1910s and 1920s had to come to terms with the overwhelming influx of new inhabitants and, consequently, with an intensification of social differences, with growing anonymity and alienation in public as well as in private spheres.

On the other hand, the immense technological achievements, the expansion of production and processing industry, of trade, administration and services created a large number of urban work places, on the factory floor, in offices and in communal administration. They provided employees - and increasingly also women employees - with better jobs, with higher incomes and reduced working hours. For the first time in history, leisure time, spare time to spend beyond providing for immediate living necessities, became a common good for a wider range of the urban population, including the middle- and part of the lower-classes. The contemporary social sciences regarded this development as the emergence of a new sociological stratum, consisting of educated people originating from a bourgeois background, 
now in employment, and qualified working men and women eager to climb socially. Both shared a similar economic structure, though they differed in their mentalité, their social behaviour, desires and conditions of life. Moreover they had different tastes and different cultural preferences. ${ }^{19}$

In any case, the changes in the socio-economic structure brought about a new middle class enjoying a similar financial capacity but with a wider range of cultural practices than there had been in the traditional nineteenth-century bourgeoisie. People who moved to the city mostly came from villages and small towns and added to the new type of middle-class citizens. Many of them were young, free and (apart from their professional or occupational life) socially independent. They improved their standard of living and became within a short time sufficiently affluent to spend their leisure time on recreation, distraction or entertainment. This was of course a development generally noticeable in Western European industrial metropolises, but within Germany it was characteristic especially of the 'Reichshauptstadt' Berlin, by far the largest and the most advanced city in Germany.

The other side of the coin was a considerable increase in urban poverty among those who for various reasons missed out on the industrial boom or were more affected than others by economic fluctuations. From 1900 onwards the formation of combines increased, especially in Berlin's electrical industry (Siemens and AEG), in chemical factories (Agfa) and in urban trade. Department stores such as KaDeWe and Wertheim competed with the smaller retail trade and big banks controlled financial life. ${ }^{20}$ The outbreak of the First World War shattered the optimistic view of a prosperous happy, dancing Berlin. Now its citizens had to cope with the horrors, casualties and devastation of the war, and consequently with unemployment, urgent housing problems and shortages in all spheres of life. With benevolent humour Heinrich Zille showed in his drawings the mixture of self-confident urban behaviour and the troubles of everyday life for those who lived in the back buildings of the Mietskasernen in multifunctional and overcrowded flats, with a lack of sanitary facilities and too much alcohol. Revolutionary post-war years brought into the metropolis a higher level of unemployment than the national average. The inflation of 1923 and the consequent stabilization policy caused a further increase in short-time working, reduced wages and unemployment, which temporarily affected up to 13 per cent of Berlin's working people. ${ }^{21}$ Although at the beginning of 1925 the situation improved considerably, the world economic crisis followed only four years later. These economic variations are directly reflected in the attendance figures of cinemas (given above, in footnote 8), insofar as their rise slowed down or stagnated. Changes in urban life also left their traces in aesthetics and style. As in other fields, they affected the architectural appearance of the cinema. Modern opulence gave way to matter-offactness, or, to put it in aesthetic terms, to 'Neue Sachlichkeit' (new functionalism). The beginnings of this new sense of style, rooted in the rationalism of modern life, go back to the war years when disillusion began to spread.

The political change from the 'Kaiserreich' to the Weimar Republic in November 1918 opened up new social and cultural perspectives. Freed from an ossified monarchy and undemocratic social structures, Berlin in the 1920s gained a new character that made it, even in the eyes of Western European countries, a cosmopolitan metropolis and a new cultural capital in Europe, even though this lasted for only some fourteen years of German history.

\section{Cinemas in the City}

To give an impression of Berlin as a cinema city and of the variety it offered to the cinema-going public in the 1910s and 1920s, I will outline a typology of four kinds of picture house within the city.

At the very centre of Alt-Berlin, on the famous Friedrichstraße, at no. 101, the 'Admiralslichtspiele' opened in 1911, as part of the 'Admiralspalast' that was designed as the first 'new cosmopolitan entertainment palace' of the metropolis. Apart from the luxurious cinema on 
the $2 \mathrm{nd}$ and $3 \mathrm{rd}$ floor of the front building, this contained a Russian-Roman thermal bath, which was open day and night for its affluent patrons, four bowling alleys, a café, bar and club rooms and an ice-skating rink that took up three floors of the extended back building. The cinema had a seating capacity of 396 and presented itself as an opulent venue. Its façade on Friedrichstraße was prominently decorated with five half columns and Doric capitals made of granite stone conveying an air of classical solidity. It did not hide the fact that it was meant for the better-off. When after the war luxury did not pay anymore, the ice-skating rink became a 'World Varieté' and 'Revue Theatre', the cinema was temporarily redecorated and converted into a restaurant and later into a dance hall to attract a wider range of patrons. In 1928 it again became a talking point. Reconverted back into a cinema, it now offered a special (and cheaper) attraction: 'Ku-Ka-Ki!' This was not a new American secret society but the abbreviation for Cake, Coffee and Cinema (Kuchen, Kaffee, Kino). ${ }^{22}$ From 3pm to 6pm ticket-holders for the afternoon performance were offered free coffee, tea or hot chocolate and a piece of cake, served in the Admiral's café. Its director, an experienced entrepreneur and owner of several cinemas in Berlin, wanted to discover whether an additional afternoon performance would be worthwhile and he counted on the bourgeois habit of coffeedrinking in the afternoon. The location in the city, the site, the tasteful style and the type of patrons the 'Admiralslichtspiele' expected, make it comparable to the former 'New Gallery Cinema' (1913-1925) in London's Regent Street. This latter, the 'picture house with a tradition', with tea rooms and brasseries, saw itself as a tasteful and quiet place of recreation after shopping in busy, up-market Regent Street. Friedrichstraße was the equivalent street, where affluent Berliners would stroll and enjoy their shopping. However, the offer of free coffee and cake in a homely café did not quite have the cosmopolitan flair of Regent Street. The Berlin press, forever mocking, talked about comfy, well-fortified and content patrons. The example of the 'Admiralspalast' demonstrates how, already in 1911, the cinema was integrated within the recreational activities of well-off Berliners.

There are several cinemas that claim to be the first or oldest cinema in Berlin. Otto Pritzkow's was one of them. Run as the

'Abnormitätenkabinett und Biographen-Theater' (Curiosity Cabinet and Biograph Theatre) from 1899, it was licensed to show films from 1903, and followed that function exclusively from 1905. At that time every single film item, often lasting no longer than two minutes, needed special approval by the local police administration, no matter whether it had been already licensed in other police districts.

As 'World Biograph Theatre' the small site in Münzstraße 17, which is north of Alexander Platz (Berlin-Mitte), was a typical converted shop, long and narrow, with an entrance directly from the busy city-centre street. Soon four other picture theatres opened near by. Pritzkow's 'Filmbox', as it was later called, lasted until 1959. It was typical of this kind of place that, with no highbrow pretensions or sophisticated decoration, it offered a pub-like atmosphere. Film programmes were personally selected by the owner, who knew his patrons well and with whom he was on good terms. Going to such cinemas was a neighbourly affair, its social space almost an extension of domestic life. Most of these cinemas were equipped with a beer-bar and served both purposes, being at the same time a point to meet for a drink and to watch a spectacle for distraction. Berliners called these simple places of entertainment a 'Kintop', where you could get 'Kino' and a 'Topp', your pint of beer, for 10 pennies (Groschen) each. ${ }^{23}$

The Kintops attracted the lower-middle class and workers more than others, but there was nothing exclusive about this. Kurt Tucholsky, who lived in Berlin before 1914, described attending the performance of 'erotic films' in a Kintop. 'I had gone there to see something rather dirty; a big friend took me there who has the admirable ability to really enjoy these things'. With ironic distance Tucholsky describes several of those little scenes on the screen when, rather incongruously, the voice of a waiter broke into the silent 


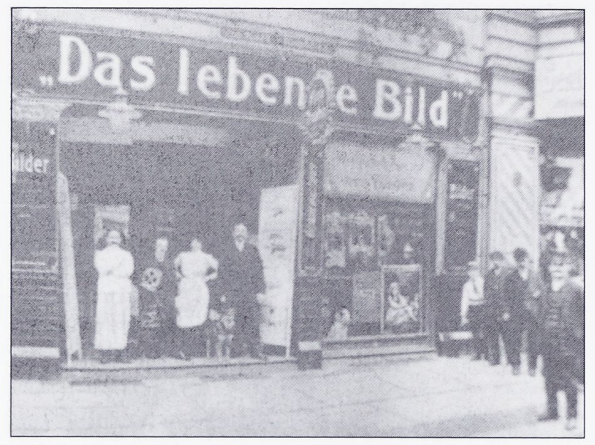

- 'The Living Picture', about 1908. The owner and his wife pose with the projectionist.

darkness offering beer. The spectators feel disturbed, somebody reacts with a quick-witted reply and from then on they freely offer their comments about what is happening on the screen. The crowd fills the cheap seats in the stalls, where 'there reigned a really gross and crude joy'. But after the performance 'the men stood around, embarrassed, regretting the lack of higher qualities... muttering that anyway that ... and anyway that ...24 Tucholsky's description carries both his immediate impression of what was going on in the Kintop and - when the lights were turned on - the embarrassment at having been a participant in it. It was not that middle-class people did not go to such places they did - but it was indelicate to admit it.

Kintops were located in the city centre as well as in other local centres, though not on the most expensive boulevards.

A third highly interesting category of cinema that had no equivalent for instance in London, was to be found spread around the dense residential areas of Berlin. Typical housing here consisted of four to six-storey tenement blocks, with several inner courtyards and extensions attached in the back. These were home to a rather mixed population. Those who could afford to lived in the front house in a spacious flat facing the street, usually on the ground floor or first floor. Upper floors were less highly valued and less expensive; backyard flats, further away from the street, often also containing workshops, were cheaper still. This sort of integrated dwelling pattern created communities which avoided rigid social segregation. There were, of course, differences within the buildings and in the status of the urban districts regarding their image, levels of rent and attractiveness. Some had a more white-collar and some a more bluecollar character; some were rather bourgeois, others were more working class. These features, however, indicate only a social tendency, not an exclusivity. In these residential areas cinemas were fitted into the tenement buildings in the middle of living quarters and, where possible, in the front building. Many of them, like the first 'Kinematographen-Theater' at Belle-Alliance Straße 99, started very early and became an attraction for the neighbourhood just like the pub around the corner. The new owner leased and converted one of the flats for his enterprise. As can be seen from the building plans of BelleAlliance which he submitted for licencing to the police authorities in September 1906, he packed his audience - in this case a maximum of 135 people - into a long, narrow room, just five-seats wide. No more than 80 square metres in total, this auditorium was made up of three or four single rooms which were originally strung together. House owners used to welcome such leaseholders because of the high rent they brought in. So the most surprisingly-shaped Kintops emerged, like the Belle Alliance, which had the screen fixed diagonally across a corner of the room because the auditorium happened to run at an angle.

In another converted cinema of this type, the 'Hohenstaufen-Lichtspiele' (built in 1907) in Kreuzberg, the tenant had to come to terms with a two-winged building, the wings joining one another at an obtuse angle. To solve the problem and to make optimal use of the available space, the inventive entrepreneur added a mirror that projected the pictures from the translucent screen in room one - which had the more expensive seats - to a second screen in room two with cheaper seating, where films could be seen at the same time, although a little darker in a mirror-image. Even if such tenement cinemas often changed hands, ${ }^{25}$ many of them survived over decades. The 'Hohenstaufen-Lichtspiele' 
altered its name and ownership several times, but existed as a cinema until 1984.

Unlike London, which from 1909 tended to build cinemas from scratch, in Berlin the building of separate cinemas started late. ${ }^{26}$ Even if newly built, film theatres usually came in the integrated pattern, either in the above-mentioned type of the Kintop in tenement blocks or, in the more commercial areas, in a combination of dwelling apartments, business premises and cinema, all in one. ${ }^{27}$ This shows how, from a very early stage, entrepreneurs and owners of premises accepted and appreciated the new entertainment as an essential part of cultural and commercial urban life; and they did so, as we shall see, in spite of the raging debate on the usefulness or the moral and cultural dangers of this new invention.

A fourth category is the picture palaces, which were most famous for their imposing style and which beyond their luxurious material presence, carried a strong and special image in urban public consciousness. They stood less obviously for making money out of a lucrative business but - by their ambitious film programmes, attentive management and tasteful style of the cinemas' furnishings - primarily added to the selfconfidence and pride of Berlin as a metropolis and film city of paramount importance. This is expressed in a few sites which flaunted traditional architectural styles, but also a new type of modern cinema architecture for which Berlin received international recognition.

Two examples of the traditional style are the 'Mozartsaal' and the 'Gloria-Palast'. The first, originally a concert hall, located within the building of the 'Neues Schauspielhaus' at Nollendorfplatz, was converted as early as September 1910 into a cinema with a seating capacity of 924 . With its heavy ornamental interior it communicated solidity, high quality and taste. From 1922 the chief manager Hanns Brodnitz made the 'Mozartsaal' the most widely appreciated cinema in the City. His original idea of making an event out of the film showings, for instance dressing the usherettes according to the film as sailors or grisettes, was much loved by the public. The 'Mozartsaal' was re-designed in 1928

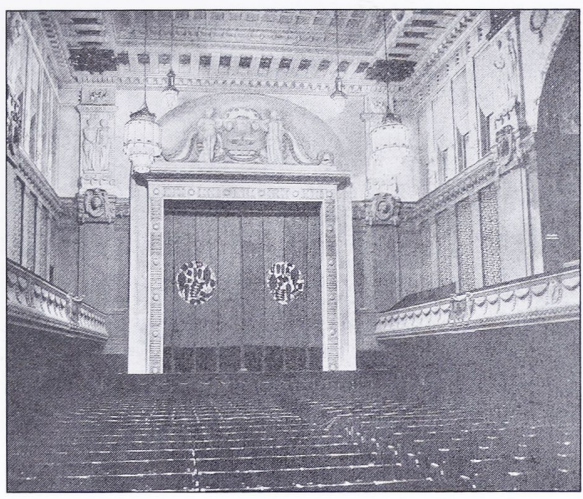

- The prestigious auditorium of the 'Mozartsaal', Nollendorfplatz, 1910. View towards the front.

by Georg Leschnitzer in the newly fashionable functionalist style of the time.

The most luxurious of the Berlin large picture palaces in the 1920 s was the 'Gloria-Palast' in the 'Romanisches Haus' (built in 1895), on Kurfürstendamm near the Kaiser-WilhelmGedächtniskirche. Its precious interior design and fittings 'alluded to a baroque-style palacetheatre' and thus adapted the historicizing, chateau-like architecture of the building. ${ }^{28}$ From its opening in 1926 until its destruction by bombing in 1943 it was the Ufa première cinema (with a seating capacity of 1200) where the people who counted in the film world met and Berlin's high society was to be seen.

What made Berlin famous across Europe, though, was its specific cinema architecture. This was assertively modern in style and as such expressed the dynamism and modernity of this young metropolis. 'Cines', built in 1913 at Nollendorfplatz, was the first completely new cinema building in Berlin. Oskar Kaufmann's monumental edifice caused a sensation: it was a compact block without any windows, following his credo that the pleasure of film-watching does not need daylight. ${ }^{29}$ With the 'Tauentzien Palast' (1914) Emil Schaudt adapted the departmentstore architecture of the time for another form of consumerism: the cinema. A whole new genre of cinemas was built according to 'lightarchitecture', with cinema facades as huge 


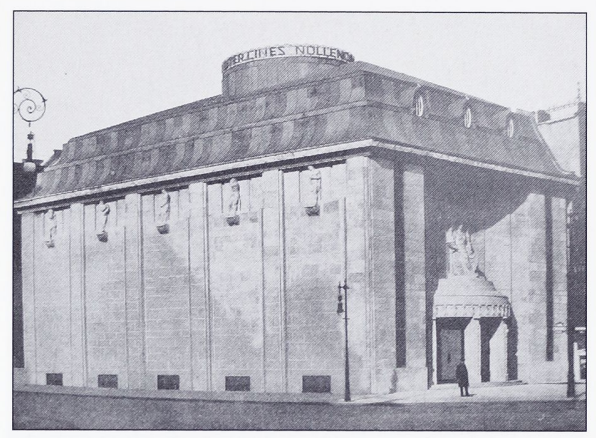

- 'Cines', Nollendorfplatz, 1913. Architectural radicalism: a cinema does not need windows

illuminated bill-boards. The 'Titania Palast' in Steglitz is such an example, built in 1926 to seat 2071, and still in use as a cinema today. Also in 1926, Hans Poelzig designed the famous 'Capitol' in Budapester Straße for the PhoebusFilm AG with 1600 seats. As the architectural historian Paul Zucker wrote, this was 'the superlative achievement of our urbanized life, it beats to our rhythm and is the most genuine expression of our time'. ${ }^{30}$ Audiences seem to have agreed and soon started to attend the huge palaces rather than the Kintops. In the late 1920 s the number of individual cinemas in Berlin dropped, while according to official statistics, the number of seats increased. ${ }^{31}$

Before 1910, Charlottenburg, the district near the Kaiser-Wilhelm-Gedächtniskirche had been a quiet and distinguished bourgeois residential area, but by the end of the decade it developed into a cinema centre second only to Potsdamer Platz (Berlin-Mitte), with eight picture palaces of more than 1000 seats and ten other cinemas. After the Second World War and the division of Berlin into 'East' and 'West' this area became the new city centre of West Berlin.

To get an overall idea of Berlin as a 'cinemacity' and to understand the distribution of the cinemas in relation to the character of their neighbourhoods, let us take a bird's eye view from west to centre, and then of the districts surrounding the centre from the north to the east. Of the more than 250 cinemas mapped on the 1925 'Kino-Pharus-Plan'32 most (38) are situated in the western district of bourgeois Charlottenburg. Thirty cinemas are in BerlinMitte, the centre of the late imperial residence, of urban and state government and administration, of business and trade and home to Berlin University, to theatres, press and of all sorts of entertainment. Between these two are the respectable areas of Wilmersdorf (10), Tiergarten (15) and Schöneberg (18). Around these, listed from north to east, the more industrial and working class areas are located: Wedding (27), Prenzlauer Berg (15), Friedrichshain (17), Lichtenberg (17) and Kreuzberg (20). Lacking the precise numbers of seating capacity for all these cinemas, we cannot calculate exactly what the sizes of their audiences were, but what is telling from the available numbers is that in 1925 more than half of the Berlin picture houses were situated in and near the city centres in the better-off districts.

It should be emphasized here that, by the time cinema arrived, Berlin was already a thriving, culturally developed metropolis, in contrast to much of the United States in the early twentieth century - from where in the 1920 s most foreign films were imported. ${ }^{33}$ For Berlin, the cinema came as an addition and was soon accepted by the public among the other forms of 'light entertainment'. There were pubs and bars (Kneipen) in great numbers and in the summer many extremely popular beer-gardens with live music. There was the Revue, stemming from France, which became popular in Berlin in the 1890s. This was so much so, that before the war larger film theatres used to include a few revue scenes before their film programmes. The Varieté, with its mixed menu of verbal and artistic originality, was a more expensive amusement than the revue, but no less frequented.

Furthermore, sporting events like soccer, boxing and cycle-racing were the great new attractions for a variety of publics. It is all too easy to forget that the so-called 'masses' who attended such sporting events were made up not only from the 'lower classes' but of people from all parts of society. This applies also to cinema-going, which was enjoyed by audiences from all walks of life. Here in such a vibrant and multifarious space of 
social life, cinema found its increasingly central role. However, its cultural, social and commercial function was determined by a number of specific factors to which I now turn.

\section{Cinema trade and cinema business in Berlin}

The beginnings of German film history lie in Berlin, precisely in Berlin-Mitte. It was shortly before the Lumière brothers presented their 'Cinématographe' to a responsive public in Paris and prepared to tour around the world with their momentous invention, that in Berlin Max, Emil and Eugen Skladanowsky were engaged to show their 'living pictures' on Max Skladanowsky's own invention, the 'Bioscop'. In November 1895 the show took place in front of a demanding audience of 1500 in Berlin's famous Varieté 'Wintergarten' near Friedrichstraße, right in the middle of the city and its entertainment quarter. For some years the Skladanowskys, sons of a Berlin showman, had been trying to construct a device for taking pictures and then reproducing them. They startled their neighbours and Berlin police by performing strange exercises and some dangerous-looking 'shooting' on the roof of an apartment block (at Schönhauser Allee 146), which was where they found the best light for their photography. Their very first 'audience' happened to be the patrons of a third-rate pub in Pankow (a district which in 1920 became a part of Greater Berlin). ${ }^{34}$ Undoubtedly these neighbours were not among the first payingaudience in the 'Wintergarten'. But even the inventors felt much more at home in the atmosphere of fairgrounds and ordinary pubs than on a highbrow stage. Max was an ingenious and fanatical do-it-yourself man and, unlike the Lumières, not an ambitious and clever business man. Though he patented his 'Bioscop' in November 1895, he lived for the rest of his life on the small returns from another of his inventions, the flicker book. No doubt the Lumières' success in the 1890s was as much a measure of their entrepreneurial skills and self-publicity as of their technological innovation. It was not until the 1920s that Max Skladanowsky started to claim in a showman's boastful way - to have been first and foremost in film production and reproduction, not only in Berlin but in the world. This caused a rather futile debate at a time when the film industry had already grown into a business of global scale. ${ }^{35}$

From an urban point of view it is less remarkable that there was such a debate, than that it came so late. It is characteristic of a technologically aware metropolis like Berlin that there was a highly competitive atmosphere especially in electrical inventions at that time. And Max Skladanowsky's competitor on the spot, Oskar Messter, might have played his part in making the 'film pioneer' Skladanowsky disappear into oblivion for two decades. ${ }^{36}$ But what the debate of the 1920s and 1930s shows is that despite its size - Berlin more than doubled in population between 1871, the foundation of the German Empire, and 1896, the beginning of film projection ${ }^{37}$ - the German 'Großstadt' was not yet a 'Weltstadt'. Neither the directors of the Wintergarten, Franz Dorn and Julius Baron, who bought the rights to use the invention, nor Max Skladanowsky, who agreed the contract and received 2500 Reichsmark for it, were conscious of the value and potential scope of the invention. ${ }^{38}$ Since the Wintergarten audience was used to new and changing variety attractions and curiosities it did not show more enthusiasm than normal when the first projection of moving images flickered over the screen. ${ }^{39}$ This appears to have been quite different from the enthusiastic response to the Lumières' show in the Grand Café in Paris at the end of December 1895; and to their two-stage introduction of the cinematograph to London, first at the Regent Street Polytechnic and a fortnight later in the music-hall programme of the Empire Theatre in Leicester Square.

This beginning of moving pictures in Berlin seems symptomatic of the years to come. Berlin became the capital of the German film industry and remained technically inventive and culturally lively, with Oskar Messter's innovations in film projectors and cameras and the photo-chemical developments of Agfa just two of the many technical achievements. Throughout the silent film period all the important German film studios 


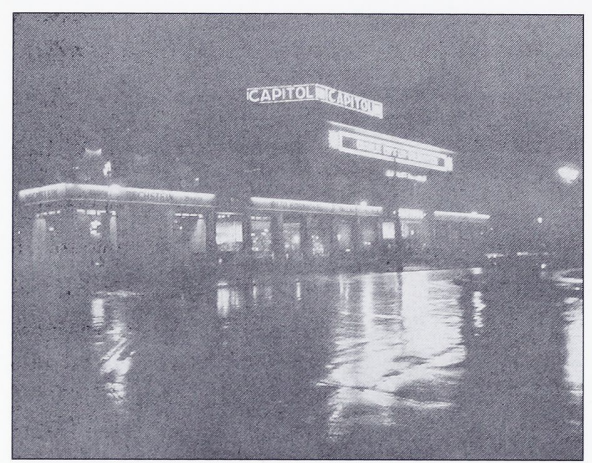

- The 'Capitol' by Hans Poelzig, 1926, Budapester Straße.

and production companies - one of which was Messter's - were based in the capital. Whoever was a film star, or hoped to become one in Germany, Austria or Scandinavia, was in the possession of a Berlin address and telephone number. The most respectable première cinemas were located in Berlin. No less important, for Eastern Europe, especially for Russia, Berlin functioned as the place of exchange for Western techniques and achievements of the highest standard and of film distribution - and this not only before the Russian revolution but also into the 1930s. And for Britain's struggling domestic industry in the 1920s, Berlin was also a beacon of sophistication and a source of expertise. ${ }^{40}$

However, mainly for political reasons, Berlin's film industry never succeeded in gaining a permanent foothold in the international business of cinema. German film production had started late, when the film market was already dominated by French companies. The most original German contribution was an artistic experimental genre, the Expressionist film, which had its heyday between 1919 and 1924, spearheaded by the success of The Cabinet of Doctor Caligari (1919). This genre and its individual examples gained international cultural recognition. But the Expressionist film itself marks a borderline. It was created in an intermediate stage of cinema as well as of film history, and emerged when German film production was economically in decline. It was clearly based on the stylistic forms of the silent film which were already becoming outdated and, most of all, it lacked the communicative relation to the mass audiences that Hollywood film was famous for. So it failed to attract the cinema-going public on a large scale. ${ }^{41}$ Its intellectuality and sophisticated allusions were aimed at educated audiences who were able and willing to reflect upon what they saw on the screen. This expectation completely overlooked the needs and desires of the post-war mass audience.

\section{'Americanization': the cultural debate}

After the First World War, German film production receded - a process that not even the concentration of the German film industry in the government backed 'Ufa' could stop. ${ }^{42}$ When in 1923-4 the German film industry had to cope with inflation, Hollywood with its powerful capital and business policy was prepared to fill the gap in the German film market. This was welcomed by the Berlin cinema-going public hungry for entertainment and distraction - more than anywhere else in Germany.

By this time the United States had become the worldwide-leading force in all three fields of the film industry: in film production, distribution and film exhibition. American film exports increased and, realizing that more money could be made at the box offices than by film production and distribution alone, ${ }^{43}$ major American companies such as Paramount, Metro Goldwyn and others started to build their 'atmospherics', picture palaces full of opulence and fantasy. They did so not just in the USA but also in Europe, first and foremost in Britain. Although within the German market, America's main impact was in film imports, in Berlin there were also American owned 'atmospheric palaces' from an early date. ${ }^{44}$ These developments had a long-term effect, not only economically, but also on the experience of cinema-goers in their cultural and social interaction.

With the ongoing 'Americanization' of the film business, a pre-war slogan reappeared in newspapers and magazines and preoccupied much of the critical public debates in the mid1920s. There was a wide front of intellectual 
opposition against the 'invasion' of American products (not only films) and ideas. Conservatives railed against American tastes and values, warning of the dangers of such cultural usurpation and nurturing the fear that the distribution of American films could affect European cultural values. In 1925 and 1926 , the contribution of American silent feature films outstripped the German contribution to the domestic market. ${ }^{45}$ Intellectuals with less conservative views expressed their fascination with America and Hollywood, or their revulsion at its superficiality. Thomas Saunders has stated this with regard to Berlin:

Forward-looking circles adopted the United States as a model of efficiency, rationalization and technological modernity. With the cultural avant-garde they revised the traditional, negative judgement on American culture. ${ }^{46}$

As we know from the statistics of Berlin cinema attendance, none of these fears in principle impinged upon the cinema-going habits of Berliners. No matter what the outcome of the intellectual debate would be, in practice the cinema-goers voted with their feet. Their film craze lay beyond intellectual arguments and was undiminished. ${ }^{47}$ After the First World War, in a defeated country, cinema audiences preferred to enjoy the pleasures of Hollywood films and the democratic appeal of the modern American way of life which they found in these films, instead of following cultural traditions and educational aims which no longer corresponded with their actual 'Lebenswelt', the world they lived in. ${ }^{48}$ They discovered their own dreams and desires in the happy scenes showing a carefree life in a New World. People in Berlin were especially receptive to this influence that reflected their own urban social and cultural experience of change in postwar Germany. ${ }^{48}$

From this point of view the character of Berlin was obviously different from other large German cities. Already before the turn of the century Berlin was occasionally characterized as 'Americanised'. ${ }^{49}$ Mark Twain called it in 1892 'the German Chicago' and he added: 'Berlin has disappeared [ . . ] The site it stands on has traditions and a history, but the city itself has no traditions and no history. It is a new city. ${ }^{\prime 50}$ What Berlin embodies here is the young metropolis, unbound and free of any commitments, a place that gives creativity a chance. Indeed, the cinema and cinema-going had become by the 1920 s a symbol of the changing forms of modernity of which the social space of Berlin was itself the epitome. Marshall Berman has characterized Modernity as a period when, perhaps for the very first time, people - mainly urban people - had the chance to 'become subjects as well as objects of modernization' and could 'get a grip on the modern world and make themselves at home in it'. ${ }^{51}$ He is well aware of the ambiguity of that 'constantly changing world' in which (as Marx warned) 'all that is solid melts into air'. But he still thinks of modernity as offering an opportunity, insofar as it could free a considerable part of the population from their personal, social and economic limitations and give it a voice that counted in public communication.

This materialistic ideal was true of Berlin as a cinema city only in public consciousness and only for a few years. Later, with 'Hollywood in Berlin', things changed - and they changed even more after 1933, which is beyond our horizon here.

Looking back to Nabokov's Laughter in the Dark we realize 'America' also plays a role in this novel, as the destination of fantasies and expectations. It is personified in three Berliners: Albinus himself, who dreams of creating a Hollywood-style animated film; Margot, the usherette, who has high-flown aspirations to become a Hollywood film star; and the man between the two, Axel Rex, whose name is as ordinary as it is presumptuous. He, 'the man of two continents' is - like the cinema - vacillating between the Old and the New World, promising to Albinus and to Margot what they want to hear and what stimulates their desires, but never comes true.

\section{Notes}

1 His father was assassinated by Russian monarchists in the Berlin Philharmonic Hall in 1922. Young 
Vladimir knew the city well from his childhood. At the age of 23 he joined the lively cultural scene of Russian émigrés in 'Russian Berlin' and here he published his first literary works. In Berlin he married Vera Slonim and their child was born. The family left Berlin only in 1937, fleeing from National Socialism to Paris and then to the USA.

2 Kamera obskura was written in winter 1930/31 and first published in the Russian émigré literary journal Sovremennye zapiski (Paris) a year later. After a reprint in Berlin (Parabola, 1934) and a very poor English translation (London 1936) Nabokov decided to rework the novel and translate it himself for an American edition. This version, entitled Laughter in the Dark (New York: Bobbs-Merrill, 1938), is the authorized text since then. My quotations are taken from this edition, New Directions, 1960, p. 7.

3 Nabokov gives precise locations for his characters in Berlin. See Dieter E. Zimmer. 'Nachwort des Herausgebers: in Vladimir Nabokov. Gesammelte Werke, vol 3. Rowohlt, 1997, pp. 555-561; and Alfred Appel, Nabokov's Dark Cinema, New York, 1974

4 As far as I know there was no cinema named 'Argus' in Berlin. But there was one of this symbolic name (alluding to the mythological guardian who sees everything with his hundred eyes) in Nabokov's prerevolutionary home town St. Petersburg. There, as a student he was an enthusiastic cinema-goer and he spent much time in film theatres. More about the Berlin-St. Petersburg connection appears in my forthcoming comparative study on Cinema in the Context of Urban Culture and Urban Society: London-Berlin - St. Petersburg, 1900 to 1930.

5 Throughout this essay the word 'cinema' is used exclusively for film theatres, that is for the site where films are shown, and not for films themselves. In English as well as in German, there is often a slippage between 'cinema' as a physical space and 'cinema' as the visual medium. Where films are meant I use the words 'film', 'movie', or 'pictures'

The films Albinus attends are hardly mentioned in the novel; they show 'happenings which he could not understand since he had not yet seen their beginning' (20). Only at the end of the novel the highly attentive reader realizes that these films have anticipated what Albinus is going to experience soon in the course of his 'real life' (288ff.). (Cf. Zimmer, p. 558.)

6 Cf. Zimmer, p. 561

7 On film, film history and film reception history, a wide range of excellent research has been done regarding Germany and the period with which I am dealing. See for example: Heide Schlüpmann, Unheimlichkeit des Blicks: das Drama des frühen deutschen Kinos, Stroemfeld/Roter Stern, 1990; Thomas Elsaesser and Michael Wedel, eds., A Second Life. German Cinema's First Decades, Amsterdam University Press, 1996; Anne Paech,
Joachim Paech, Menschen im Kino, Metzler, 2000. Apart from the often-cited Heidelberg sociological PhD dissertation by Emilie Altenloh (1914) and the consumer research led by economic interests from the 1940s, research on cinema-going became a focus only since the 1990s. Until now, the correlation between cinema-going and urban history, especially of specific cities, is still underexposed. Corinna Müller, Frühe Deutsche Kinematographie. Formale, wirtschaftliche und kulturelle Entwicklungen, Metzler, 1994; Irmbert Schenk, ed., Erlebnisort Kino, Schüren, 2000; Iris Kronauer, Vergnügen, Politik und Propaganda. Kinematographie im Berlin der Jahrhundertwende (1896-1905), unpublished Berlin PhD dissertation, 2000.

8 The statistics on cinema attendance in Berlin, systematically ascertained for 134 cinemas of all sizes, show this for the years 1919 to 1925 . The attendance changed as follows (number in millions) 1919: 9.9 m; 1920: 5.6 m; 1921: 6.1 m; 1922: 6.6 m; 1923: 6.1 m; 1924: 5.9 m; 1925: about $6.8 \mathrm{~m}$ (the last number can only be estimated because the value of the last quarter is missing) Karl Wolffsohn, Jahrbuch der Filmindustrie, 2nd vol. 1923/1925, Berlin, Lichtbildbühne, 1926, p. 231

9 See Clemens Zimmermann, 'Kino und Stadt Europäische Perspektiven', Die alte Stadt 3/2001, p. 189, and the present author's 'Zwischen Intimität und Öffentlichkeit. Kino im Großstadtraum: London, Berlin und St. Petersburg bis 1930', in Clemens Zimmermann, ed., Zentralität und Raumgefüge der Großstadt im 20. Jahrhundert, Steiner, 2006, pp. 135-152

10 Wolffsohn, p. 187

11 Such contacts were not always welcome. The police archives of Western cities house large stocks of records referring to complaints about indecencies in cinemas.

12 A most impressive collection of documents on intellectual positions of the Weimar Republic, the interim period between German Monarchy and the rule of National Socialism is Anton Kaes, Weimarer Republik. Manifeste und Dokumente zur deutschen Literatur 1918-1933, Metzler, 1983, p. VII. See also Jost Hermand, Frank Trommler, Die Kultur der Weimarer Republik, Nymphenburger, 1978

13 Siegfried Kracauer, 'Der Kult der Zerstreuung. Über die Berliner Lichtspielhäuser', in Das Ornament der Masse, Suhrkamp, 1963, pp. 311-317; in the English edition: 'Cult of Distraction', in The Mass Ornament. Weimar Essays, Harvard, 1995, pp. 323330.

14 From the numerous articles on 'Americanism' I shall mention only a few. Documents on the topic from the 1920 s appear in Kaes, Manifeste und Dokumente, pp. 265-286; in the English edition published by Anton Kaes, Martin Jay, Edward 
Dimmendberg, eds., The Weimar Republic Sourcebook, University of California Press, 1994. pp. 393-411. See also Thomas J. Saunders, Hollywood in Berlin. American Cinema and Weimar Germany, University of California Press, 1994, esp. chapter 4; Miriam Bratu Hansen, 'America, Paris, the Alps: Kracauer (and Benjamin) on Cinema and Modernity', in Leo Charney, Vanessa Schwartz, Cinema and the Invention of Modern Life, University of California Press, 1995, pp. 362-402; Alf Lüdtke et al., eds., Amerikanisierung. Traum und Alptraum im Deutschland des 20. Jahrhunderts, Steiner, 1996 Ralf Thies, Dietmar Jazbinsek, 'Berlin - das europäische Chicago', see fn. 50; Jürgen Reulecke, 'Das Berlinbild: Was ist Imagination, Was Wirklichkeit?', in Gerhard Brunn, Jürgen Reulecke, eds., Berlin ... Blicke auf die deutsche Metropole, Hobbing, 1989.

15 See the contributions to these topics for instance in the journal Der Kunstwart, 1913-1915

16 Siegfried Kracauer, 'Film und Gesellschaft', Frankfurter Zeitung, 11-19 March 1927, under the title 'Die kleinen Ladenmädchen gehen ins Kino', reprinted in Das Ornament der Masse, pp. 279-294; in the English edition: The Mass Ornament. Weimar Essays, pp. 291-306. Despite his critique of the effects of film propaganda Kracauer was convinced that film production reflected the actual dispositions of collective memory and satisfied the necessities of the masses. See his introduction to: From Caligari to Hitler. A Psychological History of the German Film, Princeton, 1947

17 See the theoretical article by Karl Christian Führer, Knut Hickethier and Axel Schildt, 'Öffentlichkeit Medien - Geschichte. Konzepte der modernen Öffentlichkeit und Zugänge zu ihrer Erforschung', in Archiv für Sozialgeschichte 41, Dietz, 200); and two historical analyses: Clemens Zimmermann, 'Das aktive Kinopublikum' and my own 'Kino und InsKino-Gehen als Stadterfahrung bis 1930. England und Russland im Vergleich', both in Die alte Stadt, 3 , 2001, pp. 189-193 and 217-229.

18 It covered in 1915 an area of $65.72 \mathrm{~km}^{2}$, with 22 districts. The number of inhabitants in 'Alt-Berlin' alone was in 1871:0.8 m; in 1895: $1.7 \mathrm{~m}$; in 1910: $2.1 \mathrm{~m}$; in 1915: $1.8 \mathrm{~m}$ and in 1918 after the war: $1.7 \mathrm{~m}$. After the incorporation of 8 towns, 59 villages and 27 estate districts into the urban unity 'GroßBerlin', in 1920, Berlin consisted of 20 districts. They covered a terrain of $878.1 \mathrm{~km}^{2}$ with a population in 1920 of $3.9 \mathrm{~m}$ and in 1930: $4.3 \mathrm{~m}$. In the 6 core city districts (Mitte, Tiergarten, Wedding, Prenzlauer Berg, Friedrichshain and Kreuzberg) in $19201.9 \mathrm{~m}$ people lived on $66.92 \mathrm{~km}^{2}$. That makes an average density of 28,500 persons per $1 \mathrm{~km}^{2}$. See Herbert Schwenk, Lexikon der Berliner Stadtentwicklung, Haude \& Spener, 2002, pp. 143, 253-254.

19 See the analysis by Theodor Geiger, Die soziale schichtung des deutschen Volkes, Stuttgart 1932. repr. Enke, 1967, p. 29. Similarly, but without abandoning the concept of 'classes', a 'frequently traversed class frontier' is supposed also for Britain at that time 'between the upper-working class and the lower-middle class' by José Harris, Private Lives, Public Spirit: Britain 1870-1914, Penguin, 1993 p. 8. Cf. Harry Braverman, Die Arbeit im modernen Produktionsprozeß, Frankfurt 1977, p. 225 ff. and more recently and especially referring to Berlin, Berthold Grzywatz, Arbeit und Bevölkerung im Berlin der Weimarer Zeit, Berlin, Colloquium, 1988, p. 3. Leisure time, in German 'Freizeit' or 'Muße', was until the nineteenth century a privilege of the upper class and property-owning families who could afford to live off their private means.

20 Laurenz Demps et al., Geschichte Berlins von den Anfängen bis 1945, Berlin: Dietz, 1987, pp. 475491.

21 Grzywatz, pp. 37-48.

22 Reichsfilmblatt, $45 / 1928$, p. 28 and $47 / 1928$, p. 31; Der Kinematograph (Berlin), 25 Nov. 1928, no. 1186, p. 15.

23 This is only one of many explanations of the word Kintop (sometimes also written as Kintopp or Kientop). When, in 1912, smoking in cinemas was prohibited and the licence for selling alcohol was limited, people grew angry and stayed away for a while. See Kurt Laser, 'Der Film in Berlin und Umgebung von den Anfängen bis 1914', in Berlin in Geschichte und Gegenwart. Jahrbuch des Landesarchivs Berlin, 2001, p. 140

24 Kurt Tucholsky, 'Erotische Films', in Jörg Schweinitz, ed., Prolog vor dem Film. Nachdenken über ein neues Medium 1909-1914, Lapzig: Reclam, 1992, pp. 51-54.

25 Wolffsohn Jahrbuch, pp. 221, 226, 251. For a Kintop with 100 to 200 seats on the outskirts of Berlin in 1910 the owner had to pay a rent of 5000 to 8000 Marks p.a. In the same year entrance fees were 10-30 pennies (Groschen).

26 The Cinematograph Act of 1909 in Britain triggered a cinema-building boom.

27 Further examples are: 'Marmorhaus' (1912/13), 'Roland-Lichtspiele' (1910), 'Schlüter' (1912), all in Charlottenburg and 'Babylon' (1927), 'Bavaria' (1912/13), 'Scala' (1908), 'Union-Theater' (1909), all in Berlin-Mitte.

28 Heinz Frick, Mein Gloria Palast, Universitas, 1986, p. 50 .

29 Sylvaine Hänsel and Angelika Schmitt (eds.), Kinoarchitektur in Berlin 1895-1995, Reimer, 1995. p. 153.

30 Paul Zucker, Theater und Lichtspielhäuser, Berlin 1926, p. 131

31 Uta Berg-Ganschow and Wolfgang Jacobsen, eds, Film, Stadt, Kino, Berlin, Argon, 1987, p. 19.

32 The 'Kino-Pharus-Plan Berlin' is a unique undertaking by the Berlin map publishers Pharus and Mattisson, editors of the Berlin Cinema Directory. 
Their map of the cinematic Berlin City was first published in 1910 and in revised editions again in 1919 and in 1925. Each black dot marked a 'Lichtspieltheater', each hatching a cinema under construction and each X stood for a Lichtspieltheater of Phoebus-Film Company.

33 In 1925803 films were imported from America, 228 were produced by the German film industry. (Wolffsohn Jahrbuch, p. 284) The number reported by Saunders, Hollywood in Berlin (p. 54) for American imports in 1925 is 607 . This differs considerably and seems far too low.

34 Wim Wenders made a dramatised film about the Skladanowsky brothers in 1995, Die Gebrüder Skladanowsky, based on an exercise with film school students.

35 See Jürgen Trimborn, 'Max Skladanowsky und der Erfinderrechtsstreit der dreißiger Jahre', in Sammlung Max Skladanowsky. Aus dem Nachlaß eines Filmpioniers, Köln, Leppin, 1997, pp. 11-22; Joachim Castan, Max Skladanowsky oder der Beginn einer deutschen Filmgeschichte, Stuttgart 1995, p. 122ff.; Thomas Elsaesser, Filmgeschichte und frühes Kino. Archäologie eines Medienwandels, edition text + kritik, 2002, p. 34

36 Iris Kronauer, p. 14, fn7.

$37 \mathrm{H}$. Silbergleit, ed., Statistisches Jahrbuch der Stadt Berlin, Berlin 1920, p. 5. of fn18.

38 F.-B. Habel, Das war unser Kintopp! Die ersten fünfzig Jahre: Von den Lebenden Bildern zum UfaTonfilm, Schwarzkopf, 1995, p. 22. On the Skladanowskys in general cf. also the earlier publication: Friedrich von Zglinicki, Der Weg des Films. Textband, Olms, 1979

39 Knut Hickethier, 'Am Anfang der Elektrifizierung der Kultur - die ersten Filme und die Idee des Fernsehens', in Harro Segeberg, ed., Die Mobilisierung des Sehens, Fink, 1996, pp. 357-377; Jeanpaul Goergen, Das Jahr 1896, Siegen 1998 They refer to the press reports.

40 Following a change in fiscal regulations in 1923, British filmmakers began to shoot regularly in Berlin's better-equipped studios, led by the producers G. B. Samuelson, Herbert Wilcox and Michael Balcon. See Rachael Low, The History of the British Film 1918-1929, George Allen \& Unwin, 1971, p. 224.

41 Kaes, Manifeste und Dokumente, p. xxvii.

42 The 'Ufa' (Universum Film A.-G.) was founded in 1917, partly as a political means of the German Government to answer to anti-German propaganda by its war enemies, partly it was a rescue operation for the loss-making German film industry during the war. See Wolfgang Mühl-Benninghaus, Vom Augusterlebnis zur Ufa-Gründung. Der deutsche Film im 1. Weltkrieg, Avinus, 2004.

43 In 1919 the earnings which American film production companies made amounted to $\$ 90 \mathrm{~m}$, those of the box-office takings of the cinemas in America $\$ 800$ m gross. Dieter Prokop, MedienMacht und Massen-Wirkung, Rombach, 1995, p. 77. In contrast to the official statistics of the 'Reichsamt' the proportion of film import from America was much higher than officially admitted. See Wolffsohn, Jahrbuch, p. 276.

44 To give one example: in May 1924 the 'Palmenhaus' on Kurfürstendamm 193-194 opened as a première film-theatre exclusively for American films. It was owned by 'Bafag', the British American Films A. G., representing Metro Pictures Corporation, New York. See Reichsfilmblatt, no. 19, 10 May 1924, p. 26. In addition 'direct affiliation with leading German companies offered American firms [ . . . ] distribution networks and theatre chains for exploitation of their product'. Saunders, Hollywood in Berlin, p. 67. In 1925 Paramount and Metro-Goldwyn-Mayer saved Ufa by investing a few million dollars in the German flagship to protect it from bankruptcy.

45 See figures in fn. 33

46 Saunders, Hollywood in Berlin, p. 242

47 This is not contradicted by the fact that inflation temporarily brought a drop at the box offices.

48 Kaes, Manifeste und Dokumente, p. xxviii. See also: Heide Schlüpmann, 'Die Erziehung des Publikums', in Kintop 5/1996, pp. 133-146.

49 Karl Scheffler, Berlin. Ein Stadtschicksal, Berlin 1910

50 Mark Twain, 'The German Chicago', in The Complete Essays of Mark Twain, New York, 1963, p. 87. There is a great deal of literature linking America with Berlin. See also: Ralf Thies and Dietmar Jazbinsek, 'Berlin - das europäische Chicago. Über ein Leitmotiv der Amerikanisierungsdebatte zu Beginn des 20. Jahrhunderts', in Clemens Zimmermann and Jürgen Reulecke, eds., Die Stadt als Moloch? Das Land als Kraftquell? Wahrnehmungen und Wirkungen der Großstädte um 1900, Birkhäuser, 1999, pp. 53-94; Jürgen Reulecke, 'Das Berlinbild Was ist Imagination, was Wirklichkeit?', in Brunn, Reulecke, eds., Berlin. Blicke see fn14, p. 259.

51 Marshall Berman, All That is Solid Melts Into Air. The Experience of Modernity (1982) Penguin, 1988, p. 5 . 